\title{
Dynamics of Contemporary Capitalist Accumulation and the Prospects for Home Work in the Indian Garment Industry
}

\author{
Archana Prasad
}

This essay explores the interface between the structural transformations in capitalism and home work by women in the specific context of the internationalization of garment production and retail following the Agreement on Textile and Clothing (ATC) of the wTo (World Trade Organization), and with special focus on its implications for home workers in India. It shows that the position and prospects of home work in global apparel production systems are structured by the gendered character of the industrial reserve army. As we know, home workers are paid at piece-rates with an aim to depress the wages of regularly employed workers and increase productivity. In this sense, home workers constitute a part of a floating active army of labour, as they depend on and are required to work in accordance with the demand in the market. This condition not only pertains to the garment industry but also prevails in other sectors like electronics, cosmetics and automobiles, in jobs where women have "traditional skills". The perception of the employers is that the tasks performed by home workers do not require much creativity or innovation, and are "lowskill" and "repetitive" jobs that can be managed without much monitoring and control. This basic logic underlies the offshoring of jobs in the apparel industry throughout the world, and home workers are part of a larger structural transformation in global apparel production which also has an immense impact on domestic production and markets. Therefore, India's place in the world's apparel industry will also determine the position of home workers in the production chain, largely because the domestic market is also moulded by this factor.

Another important marker of the position of home workers is that they only perform given tasks, and therefore their hourly productivity is not the main concern of the employer or the contractor. The value extracted out of them is not merely through low piece-rates, but also through checks on quality, which reduce the number of pieces they are paid for. In addition, the subsidies

(C) ARCHANA PRASAD, 2022 | DOI:10.1163/9789004499614_020

This is an open access chapter distributed under the terms of the CC BY-NC-ND 4.o license. 
provided by women workers includes unpaid transport allowances to fetch raw materials and get payments, and non-payment of rent and other basic amenities that an employer is required to provide in the workspace. These subsidies constitute an important portion of the rate of exploitation and the value extracted from home workers. However, as this essay shows, this method of extraction of value has limits which arise out of the constraints to accumulation within merchant capitalism itself. Perhaps it is for this reason that corporations prefer to locate their production in factories (which get converted into sweatshops), where the employer is able to extract both absolute and relative surplus value, and therefore able to increase the rate of accumulation. This process involves two different methods of control: on the one hand, relative surplus value is extracted by increasing targets and introducing new technologies; on the other hand, absolute surplus value is enhanced by prolonging the working day beyond the socially necessary time needed by labour power to reproduce itself. This simple distinction in the forms of extraction of surplus value can only be maintained through a closely monitored system of floor management, which is possible in a sweatshop and not within the system of home work. It is therefore not surprising that slave-like conditions have appeared in different developing countries where transnational corporations and brands have offshored production.

So the question is, how does a firm decide whether to employ home workers or not? The answer to this, once again, is to be traced in systemic changes within the capitalist system. The decentering of production by apparel giants is a result of the integration of global markets through supranational arrangements, and, through these, the creation of wage hierarchies structures the current employment pattern. However, the rise in the rate of accumulation is only possible if social control over the workers and their working day is maintained through processes of management and discipline. This is not possible within the framework of home work, and therefore it is not surprising that exportoriented corporations prefer sweatshops to home work. On the other hand, the use of home workers by domestic industry is largely motivated by the need to drive down costs and deal with the influx of low-priced branded apparel products. It is obvious that the cost of production of branded transnational firms is brought down by the sheer volume of production, and the domestic players attempt to stay alive in this competition through outsourcing so that their products are cheaper.

In both cases, the forms of oppression and conditions of social reproduction differ. In the case of home workers, the conditions of reproduction of piecerate work are almost collapsed with social reproduction processes within the household. But the existence of home work is a result of the conditions 
of reproduction of the international apparel industry, which spawned homebased work in India's ready-made garment sector in the first place and then, more recently, drove the shift in emphasis to sweatshops, in the run-up to and after the ATC phase. Domestic regulatory structures, when seen in conjunction with the integration of global markets, not only define the "worker", but also influence the way in which they are integrated into the larger apparel market and its labour processes after supranational and bilateral agreements influenced changes in the organization of production. Prior to the dominance of multinational supply chains, large apparel exporters from developing countries sought markets elsewhere in the world and therefore benefited from the integration of the global apparel market. But in the post-ATC period, the removal of restrictions over imports within the Indian market not only increased their competition, but also restructured the apparel export industry through the dominance of finance capital. Such an arrangement compelled changes in the labour processes. One of the markers of this phase was that apparel supply chains considered flexibility as a key principle of their operation, ${ }^{1}$ and therefore the ease of hire-and-fire was extended beyond home workers to other workers as well. For example, the apparel sector was the first to implement fixed-term employment in India, and many of the non-supervisory staff in sweatshops were also hired on contractual arrangements and under fixed-term subcontracts that do not allow for permanent work. Hence, there is a tendency to create temporary workers who work under indecent working conditions (for instance, the Sumangali scheme in India, which is elaborated in a later section of this essay). In other words, the idea that the presence of home workers provides greater flexibility to firms and contractors, ${ }^{2}$ is probably an overstatement. Flexibility plus disciplining and control are possible in a sweatshop to a greater extent than in the case of home work. This is largely because flexibility in home work is not a result of the actions of the corporate management, but a consequence of the need of women home workers to subordinate their paid work to the function of social reproduction, which is considered their primary responsibility.

In all, the themes indicated above - management, disciplining and social control - are key to the maintenance of competition within the apparel sector. This essay highlights some of these by focusing, not on an assessment of

1 Indrani Mazumdar, Women Workers and Globalization: Emergent Contradictions in India (Kolkata, 2007); S. Satyaki Roy, Garments Industry in India: A study of two clusters (New Delhi, 2009).

2 For instance, see KimV. Eyck, "Flexibilizing Employment: An Overview”, SEED Working Paper 41 (Geneva, 2003). 
profitability but on the tendency of international corporations to centralize control over workers right down to local shopfloor arrangements through what mainstream literature has termed as "global value chains" or "global production networks". The essay elaborates its argument in the context of the emerging critique of the "value chain" and "production network" paradigm, which shows that the decentering and reorganization of production are a product of the concentration of capital, and require the disciplining and social control of labour. ${ }^{3}$

As is well-known amongst Marxist political economists, the existence of both paid and unpaid labour within a commodity is a necessary condition for the expansion of capitalism through the creation of additional capital. However, the creation of additional capital itself requires the additional recruitment of paid labour. This means that the rate of surplus extraction can only be maintained by recruiting more paid workers who produce both paid and unpaid labour. As the total cost of paid labour rises, the capacity of the capitalist to create additional capital decreases. This creates a crisis within capitalism and propels the productive system into making adjustments - both the deployment of capital and the deployment of labour - in order to come out of this crisis. Alternatively, greater extraction of unpaid labour can also be achieved through stricter disciplining and control of workers, which increases their productivity without increasing their wages. This is only possible through minimizing the well-being of workers and maintaining a surplus supply of labour or the industrial reserve army. Even today, the labour reserve consists of floating workers who are in and out of the labour force, a latent labour force that is continuously formed through processes of primitive accumulation, and paupers who are largely at the margins of the labour force.

Home workers may be located as part of a floating labour force whose presence results in a lowering of the reservation wage. This is done by restructuring

3 This is also indicated by Karl Marx in Capital, Volume 1, where he wrote that the "Production of surplus-value is the absolute law of this mode of production. Labour-power is only saleable so far as it preserves the means of production in their capacity of capital, reproduces its own value as capital, and yields in unpaid labour a source of additional capital. The conditions of its sale, whether more or less favourable to the labourer, include therefore the necessity of its constant re-selling, and the constantly extended reproduction of all wealth in the shape of capital". See K. Marx, Capital Volume One: A Critical Analysis of Capitalist Production (Delhi, 2018 [1887]), p. 436. For more recent work, see Praveen Jha, "Global Production Networks: What's Labour Got To Do With It?", in Achim Truger et al, (eds), Monetary Markets, Labour and Development Festschrift for Hansjörg Herr (Marburg, 2016); Praveen Jha and Paris Yeros, "Global Agricultural Value Systems in the South: Some Critical Issues at the Current Juncture", Agrarian South:Journal of Political Economy, 8 (January-April 2o19), pp. 1-16. 
the global system of production through investments by transnational corporations. The continuous replenishment and renewal of the industrial reserve army takes place through new forms of accumulation born out of processes of appropriation and expropriation that are undertaken by different nationstates under the influence of supranational agreements like the ATC. Thus, the so-called "value chains" represent, not a sharing of profits or a redistribution of wealth, but a redeployment of capital in a manner that remoulds the contours of the working class itself. Such a restructuring starts with the family, and requires the remoulding of institutions regulating both production and social reproduction. The appearance of home work is also embedded in such an intensifying accumulation process. As this essay shows, the tendency of capitalism to control and discipline labour limits the prospects for the development of home work, whose future will be determined by labour processes that are external to the immediate subjective context of such work. Therefore, the arguments for improving the bargaining power of home workers through skill augmentation and improved organization have their limits, as home work only serves a limited purpose for the global apparel industry.

\section{Identifying Home Workers in the Circuit of Production}

In its Convention on Home Work (Convention No. 177, 1996), the International Labour Organization (ILO) described a home worker as a person who carried out work (i) in his or her home or in other premises of his or her choice, other than the workplace of the employer; (ii) for remuneration; (iii) which results in a product or service as specified by the employer, irrespective of who provides the equipment, materials or other inputs used. The Convention made it quite clear that home workers could not be considered as "independent workers" because they did not have the "autonomy" or "economic independence" to be given the status of workers. Thereafter the ILO set up different City Groups in 1997, of which one was the Delhi Group, with the aim of harmonizing the statistics on informal employment of the member countries. This independent group of statisticians reviewed the categories that were used by the National Sample Survey Organization (NSSO). In the pre-2007 period such workers were clubbed under self-employed workers since they did not work in a relationship of direct wage employment. However, the Delhi Group did not entirely agree with this classification. In its Report of 2007, the Delhi Group recommended to the Ministry of Statistics and Programme Implementation that home workers be classified not only according to the "place of work" but also according to the nature of the contracts they had with the contractor/employer. It recognized 
home work as a variant of wage employment as the workers worked according to "particular specifications" on piece-rated work. Such a recommendation should have led to the classification of home workers as wage workers rather than as "self-employed workers". But the government did not agree with this because the official statisticians argued that:

Like the other self-employed, these workers have to meet certain costs, like actual or imputed rent on the buildings in which they work, costs incurred for heating, lighting and power, storage or transportation, etc. That means, they have some tangible or intangible means of production. Note that employees are not required to provide such inputs for production. ${ }^{4}$

In the wake of such reasoning, home workers continued to be classified as "self-employed" even when they worked in relationships of disguised wage employment.

It is because of such a classification that policy-makers have largely used the "autonomy" argument to deny the status of workers to home workers and deny them rights even though the nature of their work is largely disguised wage labour. This problem persists in the recommendation of the 2oth International Conference of Labour Statisticians, which classified home workers as "dependent contractors". Dependent contractors were defined as follows:

... workers who have contractual arrangements of a commercial nature (but not a contract of employment) to provide goods or services for or through another economic unit. They are not employees of that economic unit, but are dependent on that unit for organization and execution of the work, income, or for access to the market. They are workers employed for profit, who are dependent on another entity that exercises control over their productive activities and directly benefits from the work performed by them. ${ }^{5}$

Significantly, piece-rated workers have also been classified as dependent contractors in this resolution. This directly contradicts the understanding that piece-rate is one of the most exploitative forms of labour because the wage

4 Ministry of Statistics and Programme Implementation (MoSPI), Report of Independent Group on Home Based Work (Delhi, 2008), p. 12.

5 International Labour Organization (ILO), Resolution Concerning Statistics on Work Relationships, 2oth International Conference of Labour Statisticians (Geneva, 2018), p. 7 . 
rate is used as a controlling mechanism to devalue labour time. The autonomy and independence of the home worker is illusionary, as suggested by many, ${ }^{6}$ thereby implying that home workers ought not to be classified as people who have taken up work of their own volition, as the nomenclature of dependent contractor suggests.

The question, then, is that if home workers are tied within the circuit of production, where are they placed in relation to the others as far as the export market is concerned? The actual extent of export-oriented home work in the apparel industry is virtually unknown because of the lack of consistent data. The evidence of home workers in export-oriented supply chains is also anecdotal, with several media and non-governmental organizations report the use of home workers by international brands. However, there are no conclusive data to show how much of the production for export is actually done by home workers or the proportion of apparel home workers in the export segment. In fact, there are significant arguments to show that the increase in home work in apparel manufacture in India is largely due to the expansion of the domestic industry and market. Estimates point out that the number of home workers in the apparel sector increased from 0.41 million in 1999-2000 to 2.99 million in 2011-12, constituting about 85.5 per cent of the entire female workforce in the apparel industry. However, this increase cannot be attributed to the expansion of the export market, but to the spurt in clothing consumption within the domestic market. ${ }^{7}$ Studies show that as far as export markets are concerned, they largely looked for embellishment work for outworkers, but there was a shift in operations from the home to the sweatshop in countries where penetration of transnational capital has increased rapidly.

Scanty data from a recent study show that there are multiple employment relationships within the export-oriented industry. This includes ready-made garment units with both regular and contract labour, as well as jobbers who take out raw materials and give them to outworkers. There is not much information about who these jobbers are and how many workers they have at their command. Table 17.1 gives some rudimentary estimates.

It is quite evident from the table that the relations of production in the apparel sector do not clearly demarcate between domestic and export

6 Martha Chen, Informal Economy Monitoring Study Sector Report: Home Based Workers (Cambridge, MA, 2014); International Labour Organization (ILO), "The Future of Work in Textile, Clothing, Leather and Footwear”, Working Paper 326 (Geneva, 2019).

7 Indrani Mazumdar, Home-based Work in 21st Century India (Delhi, 2018); Govindan Raveendran, Ratna Sudarshan and Joann Vanek, Home Based Workers in India: Statistics and Trends (Cambridge, MA, 2013). 
TABLE 17.1 Number of units across key clusters, 2009

\section{Cluster Number of Remarks}

units

\begin{tabular}{|c|c|c|}
\hline Kolkata & 12,291 & Knitting $7,291+$ woven cloth units 5,000 \\
\hline Mumbai & 6,000 & Manufacturer + jobbers (unspecified) \\
\hline Tiruppur & 2,500 & $\begin{array}{l}\text { Jobbers } 1,500+\text { domestic cum exporters } 500+ \\
\text { exporters } 500\end{array}$ \\
\hline Ludhiana & 2,500 & \\
\hline Indore & 2,000 & $\begin{array}{l}\text { Manufacturer cum exporters } 20-25^{+} \\
\text {manufacturer for domestic market } 45^{0}-475^{+} \\
\text {jobbers } 1,500\end{array}$ \\
\hline Bellary & 1,305 & $\begin{array}{l}\text { Big manufacturers } 5+\text { trader manufacturer } 45^{\circ}+ \\
\text { jobbers } 85^{\circ}\end{array}$ \\
\hline Jaipur & $95^{\circ}$ & $\begin{array}{l}\text { Garment manufacturing units } 250+\text { fabricators } \\
700\end{array}$ \\
\hline Bangalore & $85^{\circ}$ & $\begin{array}{l}\text { Garment manufacturing units } 35^{\circ}+\text { jobbers } 500+ \\
\text { exporters } 50\end{array}$ \\
\hline Chennai & $65^{\circ}$ & $\begin{array}{l}\text { Exporters } 100+\text { job worker } 400+\text { garment } \\
\text { manufacturers for exports } 150 \text { units, + domestic } \\
\text { players } 150 \text { units }]+ \text { jobbers } 500\end{array}$ \\
\hline NOIDA & $75^{\circ}$ & Export units $55^{\circ}+$ domestic units 200 \\
\hline Gurgaon & 675 & Export units 600 + domestic units 75 \\
\hline Okhla & $25^{\circ}$ & $\begin{array}{l}\text { All manufacturer exporters excluding fabricators } \\
\text { and embroiderers) }\end{array}$ \\
\hline Total & 30,721 & \\
\hline
\end{tabular}

SOURCE: A. MEZZADRI AND R. SRIVASTAVA, LABOUR REGIMES IN THE INDIAN GARMENT SECTOR: CAPITAL-LABOUR RELATIONS, SOCIAL REPRODUCTION AND LABOUR STANDARDS IN THE NATIONAL CAPITAL REGION, REPORT OF THE ESRC-DFID RESEARCH PROJECT “LABOUR STANDARDS AND THE WORKING POOR IN CHINA AND INDIA” (LONDON, 2015), P. 20.

production. However, surveys by different unions and agencies highlight that embroidery work constitutes the bulk of home work that is connected to export networks. A Centre of Indian Trade Unions (CITU) survey showed that embroidery accounted for about 13.6 per cent of home workers in the garment 
sector. ${ }^{8}$ Only half of this 13.6 per cent were working solely for export. In all, about 12 per cent of all home work was linked to the export market. Handwork and machine tailoring constituted about 42 per cent of the entire work, of which less than 1 per cent was linked to the export market. The same was true for handloom, which comprised about 38.2 per cent of home workers; here only 14 per cent of the work was linked to the export market. ${ }^{9}$

These estimates show that there is limited recording of home workers, largely because of their invisibility as argued by a plethora of studies. But this argument could be extended beyond the question of mere recognition; invisibility could be emblematic of the relatively weak social control of corporate houses over home workers. After all the existing data show that the paid working time of home workers is far lower than that of factory workers, even though the wages set on a piece-rated basis may be lower in such labour relations. For example, a pan-India CITU survey showed that a majority of the home workers in embroidery and other garment-related work earned below Rs 1,0oo per month and worked five to seven hours a day. This was similar to the results of an earlier survey done by the Janwadi Mahila Samiti in the National Capital Region (NCR), ${ }^{10}$ which showed that on average women home workers worked for approximately seven hours a day. However, the percentage of women working for this average time had declined from approximately 54 per cent to 30 per cent. Even this work was irregular in nature as only 39 per cent of the studied sample received work for the whole year. ${ }^{11}$ Further, most home workers were not confined to just garment work but may also be working in other sectors as and when work came their way. Hence, though home workers work long hours, they still constitute a floating labour force whose existence depresses the wages of shopfloor workers.

It should also be noted that offshoring of work has structural limits. First, most of the home workers are women who perform unpaid work in their households and also attempt to manage their work at the same time. In most cases the task of paid production is subordinated to the task of social reproduction. Second, distance from the principal employer does not enable control of quality or speed of production. Therefore the only way to extract surplus is by setting the piece-rate through an underestimation of productivity, i.e. through the setting of lower wages. In other words, surplus value is usually

8 Centre for Indian Trade Unions (CITU), Findings from Survey on Home-based Workers (Delhi, 2013).

9 Ibid., p. 40.

10 Janwadi Mahila Samiti (JMS), Survey of Home-based Workers in Delhi (Delhi, 2008).

11 CITU, Findings from Survey on Home-based Workers. 
extracted through depression of wages and through the unpaid work of supporting workers (including children). Despite all this, the capacity of home workers to contribute to the expansion of capital itself is quite limited. In this sense, perhaps the main function of the home workers is twofold: (i) to provide specialized skilled work in traditional and unmechanized niche areas like zari, zardozi $i^{12}$ and other such embroidery jobs, ${ }^{13}$ in which women are trained because of their socialization; and (ii) to provide a supplementary reserve workforce whose presence reduces the cost of labour in tasks that are not required to produce large volumes of goods. For example, the price charged by a master craftsman for zardozi work may be much higher than the cost of labour time of the home worker, which was about Rs 32 to Rs 35 per hour in $2012-13.14$

Seen in this context, the coexistence of piece-rates with time-rated wages is essential for maintaining the basic structure and high volume of the entire garment sector. The wage hierarchy created by this coexistence also ensures that the industry catering to domestic demand remains competitive in a market that is increasingly dominated by international brands and imported garments from countries like China and Bangladesh. ${ }^{15}$ The cheapness of the branded products is due to their volumes and the scale of productive activities within highly controlled labour processes. On the other hand, the survival and competitiveness of those who produce for the domestic market are maintained through their penetration into local and rural markets where the big brands have not had the same intensity of penetration. Evidence of this is seen in the fact that the size of the domestic apparel market was about USD 59 billion in 2015, whereas the size of the export apparel market was only USD 17 billion, i.e. about 22 per cent of the entire production. ${ }^{16}$ Nevertheless, the presence of home workers in the domestic market is a feature that is largely structured by the level of integration of the apparel market into the global system.

12 Zardozi is heavy embroidery with silver or gold metallic threads on silk or satin cloth. Zari is fine gold or silver thread used in traditional garments, largely in South Asia and the Middle East.

13 Mazumdar, Home-based Work in 21st Century India.

14 CITU, Findings from Survey on Home-based Workers.

15 Mazumdar, Home-based Work in 21st Century India; Technopak, Study on "Garment Sector to Understand Their Requirement for Capacity Building" (Delhi, 2018).

16 Wazir Advisors, Existing FTAs and Their Impact on Indian Textile Exports (Delhi, 2016). 
The integration of the apparel markets and production regimes following supranational and regional arrangements has influenced labour regimes in the export-oriented industry. Increased productivity and efficiency are seen as key for maintaining an edge within the highly competitive scenario. The place of a particular country's apparel exporters within the entire garment supply chains is dependent on the way in which brands develop supply chains, especially in relation to existing competence, labour surpluses and conditions of production. The main indicators of these are the comparative wages, labour regulations and the areas of product specialization. These factors influence the place of a country in the global apparel export market. The discussion below shows how social control on the shopfloor is a crucial aspect for remaining competitive in the export market, and therefore marginalizes home work in export-oriented production.

The structure of the global apparel trade was dominated by West Europe, North America and East Asia, which together with South America and Southeast Asia produced 85 per cent of the value added in the apparel sector. Production was largely domestic or regionally oriented, and at least 8 o per cent of value added derived from the production of final outputs within the region. By 2011 the relative importance of North America and West Europe declined as far as apparel production was concerned. The decrease in value added in these regions was compensated by an increase in the shares of East Asia, South and Southeast Asia, and South America. This pointed to an increase in the number of regions integrated into the global value chains in apparel. The destinations of intermediate goods supplied by the region were diversified. By 2011, Asia had become the key region of global textile and apparel production. East Asia's value added share in the world increased from 24 per cent in 1990 to 33 per cent in 2011, while South Asia and Southeast Asia's share increased from 6 per cent to 10.5 per cent. Production links between the developed and developing countries were strengthened and expanded after 2011. ${ }^{17}$

The post-crisis phase of 2008-09 saw a contraction in the size of the wearing apparel global market. Between 2008 and 2010 the annual growth rate of exported final apparel products in the world market was -1.8 per cent, whereas the demand for exported intermediate apparel products remained somewhat unchanged. This meant that countries, especially in South America, that exported fabrics and textiles faced a recession in apparel exports since there

17 World Trade Organization (wTO), World Textile and Apparel Trade in 2016 (2017). 
was no demand in the world market. Thereafter, the market recovered a little between 2011 and 2015, when the annual growth rate was about 4.8 per cent for final apparel products; but this was still about 1 per cent lower than the pre-crisis level. For intermediate products too, the annual growth rate slowed down from 12.5 per cent in the pre-crisis period to 2.7 per cent in the post-crisis period. In this period, the highest percentage increase as a share of all exports was in the South Asian region, with Bangladesh, Sri Lanka and Pakistan registering significant increases in wearing apparel exports from their own countries. In comparison, apparel exports from India rose at a much slower place. Overall, we can conclude from Table 17.2 that long-term trends in the apparel export market have seen significant shifts in the regional basis of apparel production, with India, China and Bangladesh forming an important part of the supply chains in South Asia.

Long-term trends in the apparel export market show that there has been a steady decline in growth rates of apparel production, and this has had an impact on the nature of labour relations. It is obvious that corporations in the apparel export business would find ways of cutting costs to manage competition. This forms the context of the development of global value chains in the sector which is based on offshoring of production activities. Long-term trajectories of change have been seen in the offshoring of activities in the textile

TABLE 17.2 Growth rates within apparel value chains (CAGR) in select countries

\begin{tabular}{|c|c|c|c|c|}
\hline \multirow{2}{*}{ Country } & \multicolumn{2}{|c|}{ Final apparel } & \multicolumn{2}{|c|}{ Intermediate apparel } \\
\hline & 2000-09 & 2010-15 & 2000-09 & $2010-15$ \\
\hline World & $5 \cdot 97$ & 4.8 & 12.5 & 2.7 \\
\hline Mexico & -7.88 & 0.33 & -9.43 & 1.03 \\
\hline Thailand & 1.23 & $-3 \cdot 9$ & 3.62 & -2.68 \\
\hline China & 12.73 & $5 \cdot 97$ & 12.93 & $7 \cdot 98$ \\
\hline Vietnam & 18.49 & 16.1 & 25.84 & 13.61 \\
\hline Bangladesh & 12.82 & 12.37 & 12 & 2.2 \\
\hline India & 8.02 & 10.11 & $4 \cdot 4$ & 6.24 \\
\hline Peru & $9 \cdot 77$ & -5.25 & 6.62 & 0.78 \\
\hline Philippines & $-5 \cdot 43$ & 6.02 & -8.7 & 0.68 \\
\hline Indonesia & 2.24 & 2.29 & 2.33 & 1.03 \\
\hline
\end{tabular}

SOURCE: CALCULATED FROM WORLD BANK, WORLD INTEGRATED TRADE SOLUTIONS (WASHINGTON, 2016) 
and clothing sector by the developed countries. Though offshoring started as early as the 1970s, it became a dominant and generalized trend in world textile and apparel trade between 1990 and 2015. Table 17.2 shows that the size of the global market for exports of wearing apparel contracted by about 1.10 per cent between 2000 and 2015. However, the period between 2010 and 2015 saw some recovery with the expansion of the market by 0.40 per cent. This small growth can be largely attributed to the rising trend of apparel exports in South Asia, as well as in the East Asia and Pacific regions.

However, India's largest competitor for exports emerged within the South Asia region where competition was structured through regional agreements like the South Asian Free Trade Area (SAFTA). For example, in terms of supply of intermediary products, India is the largest producer of yarn and cotton after China. It supplies yarn and cotton to Bangladesh, which has a much higher productivity of export-oriented final products in the apparel sector, especially after its greater integration into supply chains after through free trade agreements (FTAs). A recent assessment of the Ministry of Textiles, Government of India, shows that China is the only country with the capability to dominate the entire chain of international apparel production. It is the largest producer of cotton, and the second largest producer of silk, wool and man-made fibre after India. Vietnam and Bangladesh import cotton and fabric from India and China, but after China they are the overall lead exporters of finished apparel goods along with Cambodia. In fact, Indian markets are also flooded with cheap Chinese and Bangladeshi apparels, giving stiff competition to India's domestic suppliers. ${ }^{18}$

The existence of labour reserves is the main structural factor that makes South Asia an attractive destination for export houses to offshore production. The most important disciplining force in factory work is the control of the working day through labour regulations that have been liberalized under the influence of big business over the last one-and-a-half decades. The process of deregulation is designed to make developing countries like India more competitive in the international market and attract investment. The reformed labour laws provide a degree of flexibility and control to the employer, as in the case of the hiring of temporary workers (or badli workers) in Bangladesh. Such workers have fixed-term employment and often work on a piece-rated system. As a recent study notes, from 2005 to 2012 the percentage of badli workers in Bangladesh increased from almost o to 5 per cent, whereas in India the 
corresponding rise was from 8 to 10 per cent. ${ }^{19}$ The labour laws of Bangladesh and China provided for an indefinite temporary workforce, whereas India only recently introduced fixed-term contracts in the apparel sector. ${ }^{20}$ Hence the introduction of flexibility in hiring and firing seems to be one of the major factors that structures the availability of labour reserves. The second factor is the control over the working day and regulation of hours of work, including overtime. While the ILO Convention typically mandates a 40-hour working week, India, Bangladesh and Vietnam permit 48 hours a week, and China permits 44 hours a week. However, what is important is that the working week does not conform to a normal five to six-day week, and the schedule of leave permitted is oppressive. In Bangladesh, workers are allowed one day of paid leave for every 18 days of work or about 17 paid holidays annually; in India, workers get 12 paid days of leave annually. Overtime is legal everywhere with most countries permitting one to two hours of overtime at 150 to 200 per cent of the hourly wage. Another factor that comes into play in extending the working day is the "night shift". Bangladesh, Vietnam and India do not provide for premium wages on night shifts, whereas China provides a premium of 130 per cent of the hourly wage for the night shift. ${ }^{21}$

Whatever the legal framework, the working day of a garment worker in almost all these factories extends far beyond the legal limit. A recent study showed that Bangladesh women workers (constituting about 80 per cent of the workforce) work from 14 to 16 hours a day, seven days a week. ${ }^{22}$ This means that instead of 48 hours, the women actually worked for 98 hours a week. Similarly, a multi-country study of the ILO concluded that in Vietnam and Pakistan, two out of three workers worked for more than 48 hours a week, that too without receiving the stipulated overtime payment. ${ }^{23}$ The situation was similar in India: surveying about 500 workers, the study concluded that for 80 per cent of current workers a six-day working week was the norm, while 20 per cent of workers reported working seven days a week. Three-fourths of the

\footnotetext{
19 World Bank, Stitches to Riches: Apparel Employment, Trade and Economic Development in South Asia (Washington, 2016) or World Bank.

20 Technopak, Study on "Garment Sector to Understand Their Requirement for Capacity Building", p. 40.

21 Ibid., p. 41.

22 Sarpong (2018), 'Sweatshops and the Duty of Care:To What Extent? The Case of Bangladesh in Shahka Seifi and David Crowther eds, Stakeholders, Governance and Responsibility, 14 (2018), pp. 229-47.

23 Phu Huynh, Employment, Wages and Productivity in Asia's Garment sector: Finding New Drivers of Competitiveness, Working Paper Series, ILO Regional Office for Asia and Pacific (Bangkok, 2015), pp. 11-13.
} 
workers usually worked 8 hours a day but the remaining 25 per cent worked more than 10 hours, including more than 12 per cent who reported working 12 hours or more. ${ }^{24}$ However such results are very region-specific and do not cover many clusters like Coimbatore and Tirupur in the south of India, where working hours are much more oppressive and young girls were forced to work overtime without pay. The normal working day consisted of 14 to 16 hours, or 24 hours in three shifts, in export-oriented spinning factories. ${ }^{25}$

Oppressive control over the working day is possible because of the persistence of global labour arbitrage, which forms the context of the emergence of the global apparel producing and trading corporation that exploits cheap labour across the globe. As a Report of the Workers Consortium shows, between 2001 and 2011, real wages in the apparel sector fell in nine out of ten top apparel-exporting countries. ${ }^{26}$ Competition between developing countries to attract global apparel business creates wage hierarchies within the South Asian region and within the industry itself, as seen in Table 17.3.

The data show that of all the top apparel-exporting countries, Bangladesh and Cambodia (considered India's main competitors, apart from China) have declining wages, whereas China has increased its wages more than twofold. However, China's complete product range, and technological and infrastructural advantage are seen as having made up for the rising labour costs. Hence, perhaps low wages are not the only factor structuring labour practices as, despite rising wages, China continues to dominate the world market. This is seen if we compare the unit costs of production of the most popular items for export.

Table 17.4 clearly indicates that labour intensity is not the only factor contributing to domination of the world export market. The variety and technology of production also play an important role in structuring the competition. Thus, though China has a higher average cost of production as compared to India and Bangladesh in several items like coats, sweaters and sweatshirts, it still dominates the market because of the quality and breadth of its variety. This is a result of public investment in knowledge and research infrastructure, which is lacking in the other countries. Rather, countries like India and Bangladesh use labour-intensive production systems which are competitive primarily because

24 Fundamentals, Insights into the Working Conditions in India's Garment Industry (Geneva, 2015).

25 sомо and ICN, Maid in India: Young Dalit Girls Continue to Suffer Exploitation in India's Garment Industry (Amsterdam, 2012).

26 Workers Rights Consortium, Global Wage Trends for Apparel Workers, 2001-2011 (Washington, D.C., 2013), p. 7 . 
TABLE 17.3 Monthly real wages in 15 of the top 21 apparel exporters to the United States, in 2001 currency

\begin{tabular}{|c|c|c|c|c|c|}
\hline & \multicolumn{4}{|c|}{ Monthly real wage } & \multirow{3}{*}{$\begin{array}{r}\text { Per cent } \\
\text { change }\end{array}$} \\
\hline & \multicolumn{2}{|c|}{2001} & \multicolumn{2}{|c|}{2011} & \\
\hline & LCU & USD, PPP & LCU & USD, PPP & \\
\hline Bangladesh & $2,083.00$ & $\$ 93.67$ & $2,033.60$ & $\$ 91.45$ & $-2.37 \%$ \\
\hline Cambodia* & 51.00 & $\$ 161.89$ & $39 \cdot 78$ & $\$ 126.26$ & $-22.01 \%$ \\
\hline China & 480.00 & $\$ 144.86$ & $1,076.57$ & $\$ 324.90$ & $+124.29 \%$ \\
\hline $\begin{array}{l}\text { Dominican } \\
\text { Republic }\end{array}$ & $2,698.00$ & $\$ 293.5^{2}$ & $2,057.45$ & $\$ 223.83$ & $-23 \cdot 74 \%$ \\
\hline El Salvador* & 162.00 & $\$ 332.44$ & $143 \cdot 34$ & $\$ 294.14$ & $-11.52 \%$ \\
\hline Guatemala & $1,414.66$ & $\$ 397.62$ & $1,230.10$ & $\$ 345 \cdot 75$ & $-13.05 \%$ \\
\hline Haiti & $1,014.00$ & $\$ 104.42$ & $1,502.99$ & $\$ 154.78$ & $+48.22 \%$ \\
\hline Honduras & $2,514.83$ & $\$ 359 \cdot 47$ & $2,294.53$ & $\$ 327.98$ & $-8.76 \%$ \\
\hline India & $2,019 \cdot 55$ & $\$ 150.20$ & $2,281.27$ & $\$ 169.67$ & $+12.96 \%$ \\
\hline Indonesia & $421,958.00$ & $\$ 134.90$ & $583,786.75$ & $\$ 186.64$ & $+38.35 \%$ \\
\hline Mexico & $4,766 . \circ \circ$ & $\$ 755.14$ & $3,386.54$ & $\$ 536.57$ & $-28.94 \%$ \\
\hline Mexico & $1,258.00$ & $\$ 199 \cdot 3^{2}$ & $1,297 \cdot 31$ & $\$ 205.55$ & $+3.12 \%$ \\
\hline Peru & $487 \cdot 5^{\circ}$ & $\$ 335.93$ & 570.94 & $\$ 393.43$ & $+17.12 \%$ \\
\hline Philippines & 4,979.00 & $\$ 249.25$ & $4,662.19$ & $\$ 233 \cdot 39$ & $-6.36 \%$ \\
\hline Thailand & $5,748.5^{\circ}$ & $\$ 360.33$ & $5,378.25$ & $\$_{337.12}$ & $-6.44 \%$ \\
\hline Vietnam & $730,167.00$ & $\$ 182.43$ & $1,019,766.50$ & $\$ 254.78$ & $+39.66 \%$ \\
\hline
\end{tabular}

SOURCE: WORKERS RIGHTS CONSORTIUM, GLOBAL WAGE TRENDS FOR APPAREL WORKERS, 2001-2011, P. 11 .

of low wage structures. Hence low wages and their relationship with productivity targets become the main methods of control over workers.

Another important way of disciplining the workforce on the shopfloor is through quality control which takes place through wage cuts if targets are not met and there are too many rejects. An increasing tendency to make unrealistic targets is evident and is achieved by squeezing intervals between batches through mechanization or reducing the mandated time available to workers for rest; this leads to stricter disciplining and greater oppression of garment workers. A study commissioned by the Ministry of Textiles, Government of 


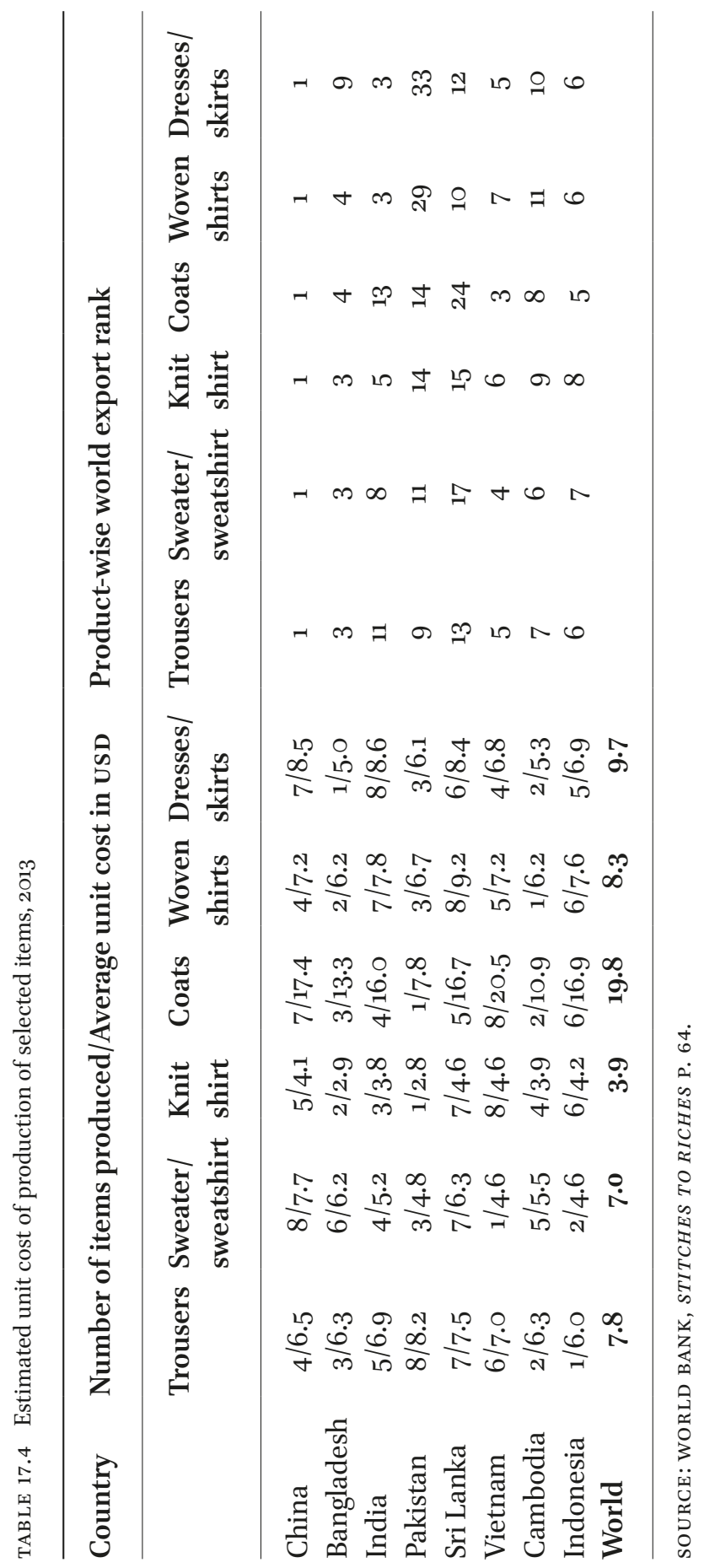


India, shows that Bangladesh and Vietnam had the least number of rejects in production. Their order to shipment ratio was also much higher than that of India. In low technology systems this is only possible when tight controls are maintained over labour time. ${ }^{27}$ This is especially the case with Bangladesh, which follows many more manual processes in designing, checking, etc., than even India and Vietnam. The Chinese industry is comparatively more automated and semi-automated in some functions, but the important point to note is that most of its machinery is self-made or of Chinese origin, whereas big export houses in India import machines from China, Japan and Germany whose cost has to be recovered from production. ${ }^{28}$ This can only be done through increases in volumes, and therefore it is not surprising that India's Ministry of Textiles is constantly demanding changes in the labour laws to enable multiple shifts (through an increase in night work) for raising production. What is important to note is that the value added by an Indian worker (measured through the lens of neoliberal economics) is only one-third the value added by a Chinese worker. ${ }^{29}$ Hence, unless there is greater investment in worker-enabled and worker-oriented technology, the social cost of which is borne by the government (as it is in China), the tendency of capital to set up a management system of daily physical control of the worker is much higher, and this cannot be done in a production organization that depends too much on home work.

These multiple features of the control of labour create conditions of production that subordinate the process of social reproduction to capitalist production processes. The rate of accumulation is largely maintained through working conditions that effectively reproduce relations of forced and unfree labour. But this unfreedom is not merely in terms of extracting unpaid labour time, but also in terms of lack of access to safe and habitable working conditions. The contemporary literature on Bangladesh and of forced work camps for young girls in the Delhi region, Tirupur and other parts of India is too vast to detail in this paper. ${ }^{30}$ But it is possible to generalize that if women workers want to make a survival wage (as most do not even get a minimum wage), they will have to work overtime and sacrifice their family life in a situation where

27 Technopak, Study on "Garment Sector to Understand Their Requirement for Capacity Building", p. 43 .

28 Ibid., pp. 23-24.

29 World Bank, Stitches to Riches, p. 65.

30 somo and ICN, Maid in India; ILo. (December 2015); International Labour Organization (ILO), Minimum Wages in the Global Garment Industry, International Labour Organization Research Note (Geneva, 2015). 
social wages are minimal. Further, the discounting of the woman's role in social reproduction is also done through recruitment practices and composition of the workforce. The highest demand is for women workers between the ages of 12 and 29 years, i.e. young workers whose burden to perform functions of social reproduction is somewhat lower than that of older women. But employment in these age groups also ensures the perpetuation of certain patriarchal values wherein older women with double burdens are considered a liability for the workplace. This can be illustrated through the example of the Sumangali scheme of Tamil Nadu, where contracts are signed with the parents of the girl worker for payment of a specified amount over a period of three to five years, money that can be saved as dowry for their daughter. The girl worker is made to live in a dormitory under abysmal conditions and overworked. A part of her wages is withheld till the contract period is over. These young girls supply labour to big garment manufacturers that service the European and American markets. ${ }^{31}$ Such a scheme not only reproduces the supply of cheap labour, but also perpetuates and strengthens patriarchy within the family. However, the reproduction of patriarchy is a secondary objective, the primary aim being to ensure a perpetual supply of cheap labour which functions in slave-like conditions because of the oppressive character of sweatshop management, needed to maintain a competitive advantage. Further, the intensification of super-profiteering and rate of accumulation within the apparel sector cannot be maintained in the long term without direct and repressive control over the labour process. This is only possible if the organization of production is done at centralized workplaces, and this underlying tendency limits the prospects for the growth of home work within the export-oriented industry.

\section{Conclusion}

This essay focuses on the dynamics of labour processes within the exportoriented garment sector, and their implications for the present and future prospects of home work. It uses Marx's General Law of Capitalist Accumulation to show that there is an increasing tendency within capitalism to have centralized social control over labour processes in order to cope with the high competition that emerges from the internationalization of capital. This pattern is evident in the global apparel industry, where sweatshop management is emblematic of the way in which the workforce is disciplined through a mix of coercive 
and non-coercive processes, which subordinate the function of social reproduction to the larger accumulation strategy. The analysis shows that this is not possible if there is a preponderance of home work within the export chain. Therefore, home work plays a limited role in ensuring that wages in the production of certain niche products such as embroidered clothing remain low. However, as is also evident from the analysis, home workers have a greater role in enabling the survival and viability of domestic businesses that are struggling to cope with increasing international competition in the period after 2005. It must be noted that decentred networks of domestic production, where home work plays an important role, may have emerged as the result of a restructured export orientation of Indian apparel industry, but competition from international brands in the post-ATC period also places constraints on the expansion of domestic production. This in itself can be a constraining factor in the future prospects of home work in the apparel sector.

It is important to debate the future of home workers in the context of the structural transformations and tendencies in the global apparel sector under contemporary capitalism. This may be done by a cursory consideration of some important contentions which argue that skill augmentation and social dialogue with multinational corporations can result in a brighter future for home workers. ${ }^{32}$ However, as this essay shows, such a contention is of limited value and can only help the workers to overcome short- and medium-term crises of survival. Such measures will not challenge the basic structural constraints which limit the growth of home work because of the dominant tendencies within capitalism itself. This is largely because women need to be freed of their care and family responsibilities if their participation through home work is to become meaningful. Since the unpaid work of women subsidizes costs of production in contemporary capitalism, home workers have to be recognized as "workers" both within the network of industrial production and at home. The analysis in this essay shows that the recent categorization of home workers as "dependent contractors" in the recommendations of the 2oth Conference of the International Conference of Labour Statisticians is therefore counterproductive, even from the limited objective of improving the working conditions of home workers.

Finally, from the perspective advanced in this essay, home work can only be emancipatory for women if it enables them to unleash their creative abilities without the burden of a bulk of the tasks associated with social reproduction.

32 ILO, "The Future of Work in Textile, Clothing, Leather and Footwear"; Chen, Informal Economy Monitoring Study Sector Report. 
It is obvious that neoliberal capitalism is incapable of achieving this objective because it has an inherent tendency to privatize, not socialize, social reproduction. This is possible, therefore, only by challenging the very basis of the capitalist system. In this light, it is important to consider whether home work has any relevance outside the system of capitalism, especially where social reproduction itself is socialized and does not require women to stay at home. Since this is a distant dream, the ongoing partial struggle for recognizing women as legitimate "workers" must continue and be intensified. 